\title{
Panel on: The Problems and Prospects of Teaching in the Digital Age
}

\author{
Personally Authenticating the Digital Divide \\ Xin-An (Lucian) Lu and Hong Wang \\ Shippensburg University of Pennsylvania, Shippensburg, PA, USA
}

\author{
xalu@wharf.ship.edu howang@wharf.ship.edu
}

\begin{abstract}
Is technology equalizing or polarizing this world? The authors answer this question by personally authenticating the dramatic state of the digital divide via their own experience. First, the authors will define "digital divide. Second, justification will be given to the significance of the issue. Third, with citation of research literature, the authors will substantiate the gravity of digital divide in our world. Finally, adducing their own personal experience, the authors intend to clinch the point that the digital divide is not distant and impersonal, a concern of someone else, but close, real, and very personal. The authors' multi-regional and multi-national experiences put them in a poised position to explore and reflect upon the issue of the digital divide.
\end{abstract}

Keywords : digital divide, technology, ICT, polarization

\section{Defining the Digital Divide}

As Sachs (2000) has observed: "[T]oday's world is divided not by ideology but by technology ... A small part of the globe, accounting for some 15 per cent of the earth's population, provides nearly all of the world's technology innovations. A second part, involving perhaps half of the world's population, is able to adapt these technologies in production and consumption. The remaining part, covering around a third of the world's population, is technologically disconnected, neither innovating at home nor adopting foreign technologies" (p. 99). In this section of the work, the authors will define what constitutes as the digital divide.

Historically, periodical indices show 1996 as the first year the digital divide leapt into the spotlight as a focus of public attention and action, although the origins of the term are unknown. The Clinton administration's National Telecommunications and Information Administration (NTIA) issued a report in 1995 calling attention to information "haves" and "have-nots," without mention of a digital divide (NTIA, 1995). A second NTIA report in 1998 and its accompanying publicity helped to popularize the term. Three commonly reported shorthand definitions equate the digital divide with a "disparity between various groups in the areas of computer and Internet use" (Henderson, 2000, p. 60), differences between information haves and have-nots ("Digital divide' does beyond internet access," 1999), and disparities in

Material published as part of these proceedings, either on-line or in print, is copyrighted by Informing Science. Permission to make digital or paper copy of part or all of these works for personal or classroom use is granted without fee provided that the copies are not made or distributed for profit or commercial advantage AND that copies 1) bear this notice in full and 2) give the full citation on the first page. It is permissible to abstract these works so long as credit is given. To copy in all other cases or to republish or to post on a server or to redistribute to lists requires specific permission from the publisher at Publisher@InformingScience.org computer ownership and computer usage (Crews, 2000; Light, 2001).

The term "digital divide" is generally used to describe situations where there is a conspicuous gap in access to or use of information and communication technology (ICT) devices measured by, for instance, the number of phone lines per inhabitant, or the number of Internet users, or of mobile 
telephones in the population. The digital divide can be within a country or between countries. In the former case, the digital divide usually exists between young and old, male and female, the more and the less educated, the more and the less wealthy, and urban and rural locations. In the latter case, the digital divide gene rally refers to that between industrialized and developing countries -- although comparisons of ICT use at different spots on the world map are now almost as significant as inter-country comparisons (Campbell, 2001). For example, regarding Internet usage, Beijing may be the same with Washington, DC but greatly different from rural China.

However, another type of the digital divide is often given inadequate attention-the artificial or virtual digital divide. The artificial or virtual digital divide is defined not in terms of the gap in access to or use of ICT devices, but in terms of artificially blocked access to electronic information despite the physical existence of ICT devices ready for use. For instance, millions of Chinese users of the Internet cannot benefit from significant information that can advise their decision-making as a citizen, simply because such information is blocked by the government. The gap in access to information (besides that in terms of information technology) can be defined as another type of the digital divide, the artificial digital divide. This is why Menou (2001) raised the following questions in the digital divide debate: Connected to what? Connected for what? Menou contends that the simple fact of being connected in itself may not automatically bring all possible economic, educational, cultural or social benefits that ICT devices can provide. This is also perhaps why Lu (2001) argues that the digital divide is not only a technical issue, but can rather be a reflection of broader social problems.

Gates (2000) defines the digital divide in terms of "cyber-segregation." Recalling historical repression that denied African Americans communicative freedom via the "mastery of letters and mastery of drums," Gates (2000) argued, "Today, however, blacks are facing a new form of denial to the tools of literacy, this time in the guise of access to the digitalknowledge economy" (p. 72). Therefore, the digital divide is far from being a mere technical issue; it has far-reaching social, economic, and educational impacts. The next section of the work justifies the significance of the issue of the digital divide.

\section{Justifying the Significance of the Issue of Digital Divide}

Abundant research has asseverated that the digital divide is an issue of grave significance. The seemingly technical divide has lasting social, economic, and educational impacts. In this section, the authors will affirm and justify the significance of the issue of the digital divide by citing recent research literature.

The digital divide is a very serious matter for those who are currently behind in Internet access, for they are not able to enjoy many benefits of being wired and are handicapped in participating fully in society's economic, political, and social life (Howland, 1998; Office of the Press Secretary, 1999). These benefits include finding lower prices for goods and services, working from home, acquiring new skills using distance education, making better-informed decisions about their healthcare needs, and getting more involved in the education of their children. The list of benefits can go on. Thus, citizens of deve loping countries, because of lagging behind in Internet access, may lag further behind in economic progress and in the quality of life (Lu, 2001).

"If you have seen what [technology] has done for you and for this economy, . . closing the digital divide is one of the most important things we can do to have the quickest results in alleviating the kind of poverty that is inexc usable in the kind of economy we are experiencing today" (President Bill Clinton, cited in Benedetto, 2000, p. 13A). 
Studies describing and measuring the digital divide and the policy reports that use those studies, tend to share two basic assumptions: that introducing computers mitigates inequality, and that life in the new geography of cyberspace frees individuals from other social constraints. In other words, access to the economic potential of an Information Society holds the potential to alleviate critical problems faced by the disadvantaged, yet the disadvantaged lack access to that potential (Goslee, 1998; Crews, 2000; Lacey, 2000b; McKee, 1999; Poole, 1996; Light, 2001).

Menou (2001) contends that ICT is one of the most potent forces in shaping the twenty-first century. Its unprecedented impact affects the way people live, learn, and work. ICT has greatly changed the way government interacts with civil society and has become a vital engine of growth for the world economy. It is enabling aspiring individuals, firms, and communities, in countless parts of the globe, to address economic and social challenges with greater agility, efficiency, and creativity. In short, ICT promises enormous opportunities for its users. As one illustration, people with Internet access can easily execute many routine businesses by visiting the websites of governmental age ncies. However, millions of people in rural China, who do not have this access, have to depend on the snail mail. Frequently, they even have to take days and months to phys ically travel to the governmental agencies to do routine businesses or express their grie vances.

Theoretically, Campbell (2001) argues that ICT will necessarily lead to positive economic outcomes by making markets more transparent through greater access to information, and more efficient through the resulting decline in transaction costs. Empirical studies reviewed by Smith, Bailey and Brynjolfsson (2000) do find that prices are lower in electronic markets compared with those in conventional markets. Krueger (2000) also observed improvements in the labor market because of ICTs that promote job search efficiency. Online job search tends to speed up the matching process and to be a factor in lower unemployment.

Evidence shows that durable productivity gains have been greatest in enterprises where ICT use has been greatest (Bresnahan, Brynjolfsson \& Hitt, 1999). At the aggregate level, the growth in multi-factor productivity in the late 1990s (compared with a decade earlier) was greatest in countries where ICT use was most widespread. These were countries where employment growth was greatest. Furthermore, ICTs are also associated with growth in the service sector, including "intangible" markets -- markets in which the product itself is digital, such as software development (Campbell, 2001).

Some evidence suggests a two-way causality, that is, wealthy countries can afford better telecommunications, and that better telecommunications are also a determinant of economic opportunity. Studies by World Bank show that as much as one half of the difference between Africa's manufacturing exports as a share of GDP and the much higher east Asian share may be caused by the former's poor telecommunications (World Bank, 2000). Evidence for Botswana and Zimbabwe shows that areas without access to telephones have substantially less entrepreneurial activity (ibid., p. 20). A similar study states, "Areas with high levels of resources and skilled labor but with lower levels of telephony have fewer 'productive enterprises"' (Robison and Crenshaw, 2000, p. 5). Therefore, it is plausible that countries with poor telecommunications are poorer in turn as a result. ICT and economic growth, in this sense, promote each other.

Finally, there exists a counter-argument against more attention to the issue of the digital divide. It can be argued that connectivity is irrelevant to the three billion people in the world who live on less than two US dollars a day. For an estimated two billion people in the world, access to fresh water or electricity is of more fundamental concern than ICTs. However, higher priority for some issues is not adequate justification for the deprivation of attention to issues of a lower priority. Long-term and sustained economic growth often necessitates concurrent attention to various issues. Since ICTs could be a valuable tool in accelerating development, policymakers should consider applications of ICTs while they consider other national priorities (Campbell, 2001). 
In short, the digital divide could further entrench the economic gap between rich countries and poor countries with minimal or no connectivity, which may in turn lead to discrepant domestic growth rates and in the marginalization of the latter from the world trading system (Campbell, 2001). The resultant gap between rich and poor countries, in the long run, could be a potential threat to world peace. However, the digital divide is still inadequately addressed and remains in a dramatic state. In the remainder of the work, the authors will demonstrate the dramatic state of the digital divide in this world through statistical substantiation and personal testimony.

\section{Substantiating the Digital Divide}

Buttressed by statistics and research, this section of the work substantiates the (dramatic) existence of the digital divide. The reader will see that the digital divide exists among different races within the same country, among groups of different income, and among different locations within a country or across countries.

According to U.S. Department of Commerce (2000), from 1994 to 2000, the technology gap between blacks and whites widened, giving the impression that the problem is not correcting itself over time. Harold Wenglinsky, a research scientist for Educational Testing Service in Princeton, NJ, claims, "The digital divide is black and white. Over half of White children are online, but just 14 percent of Black children are" (reported by The digital divide: Black-white or rich-poor, 2001).

Government research during the Clinton administration suggested that digital inequalities had worsened over time. The NTIA's Falling Through the Net II (1998) and Falling Through the Net III (1999) noted that the gap in computer ownership between White and Hispanic households increased more than 42 percent from 1994 to 1998. Gaps in Internet access between White and Hispanic households and between White and African American households grew by five percentage points between 1997 and 1999. Gaps in Internet access from home between households at the highest and lowest income levels widened by 29 percent from 1997 to 1999. The NTIA's 2000 figures show White and Asian American households with 46 percent and 57 percent access, respectively, more than double the access of African American and Hispanic households, with 23.5 percent and 23.6 percent, respectively.

However, some research indicates that the gap is more connected with income level. David Card, a senior researcher at Jupiter Media Metrix in New York, notes that: "Thirty percent of African-Americans and 47 percent of Whites are on the Net." However, income level seems to be the real determinant of the gap. Seventy-three percent of those making $\$ 75,000$ annually and more are online, while just 31 percent of those making under $\$ 30,000$ and 15 percent of those making below $\$ 15,000$ are online (reported by The digital divide: Black-white or rich-poor, 2001). If computer ownership continues its rapid spread among middle-income families, as seems likely, the digital divide will shift to the bottom fifth of the income distribution, demarcating families with incomes below $\$ 15,000$ from the rest of the society. This is a racially heterogeneous stratum already facing severe educational and economic disadvantages (Attewell, 2001).

The "digital divide" is a reality acknowledged by individuals and organizations that do not always agree on education matters. CEOs of forty- five U.S. corporations, including Microsoft, Cisco Systems, and General Electric, issued a report claiming the divide as a threat to American prosperity (Light, 2001). During the 2000 U.S. presidential campaign, candidates George W. Bush and Albert Gore Jr. spoke frequently about their ideas for narrowing the divide.

However, many who are blessed with ICT may think that the digital divide is but a concern of the "Other," and is a distant and impersonal matter. Yet, with intensifying globalization, the digital divide not only divides the privileged from the under-privileged and thus may appear impersonal for the former, but can also divide the privileged from their loved ones and close friends. The digital divide is no 
longer distant and impersonal, a concern of someone else, but close, real, and very personal. In the following section of the work, adducing their own experience, the authors will authenticate the dramatic state of the digital divide and illustrate that the digital divide can be very real, close, and personal to even those blessed with all major ICTs.

\section{Personally Authenticating the Digital Divide}

In this section of the work, the authors will personally authenticate the dramatic state of the digital divide and illustrate the personal nature of this divide. First, the authors' recent and past experience will be delineated. Second, the authors will illustrate how the digital divide is immediately dividing them from their loved ones and close friends. Finally in this section, the authors will explain how governme ntal blocking of information can artificially create a "virtual digital divide" that may divide China from the "informed parts" of the globe.

Both of the authors originally come from the mainland China and received their undergraduate education in China. Currently they are both university professors in communication and culture in the United States. Their experience spans the rural and urban China and across the Pacific. The authors' multiregional and multi-national background puts them in a poised position to testify and reflect on the digital divide.

First, a clear digital divide divides the authors' present condition in terms of ICT use from their cond ition in the recent past. At present, the authors are conversant with and equipped by their University with all major ICTs. Use of ICT is an integral part of their daily routines (e.g., emailing, web searching, online teaching, and virtual meeting). They also teach computer-mediated communication to dozens of students every year. However, in terms of ICT use, the authors' recent past contrasted sharply with their present cond ition.

One author did not get to see what a computer looked like until near the graduation from his college in 1988. He greatly marveled at the fact that he could use the computer keyboard to type his own name. At that time, the author was studying at a major University in central China. Computers were almost nonexistent not only on the campus but also in the students' minds. Even the concept and image of the computer was so foreign to most college students. One author graduated from the graduate school in 1993 and his thesis for the master's degree was completely typed with the typewriter. Every tiny correction had to be made with the cumbersome "correction fluid," which necessitated several minutes of drying before resumption of continued typing. Most students in the authors' undergraduate classes could not afford a short-wave radio to receive foreign English-speaking programs to facilitate their learning of the language. There was no phone in the whole classroom building for student use. There was no phone in individual dormitory rooms. Generally there was but one phone in the whole dormitory building for all the residents' use. One had to master the important skill of running from the sixth floor down to the first floor without spraining his or her ankles just to be quick enough to avoid the fateful hanging up by the impatient phone operator. Because of this, for instance, distance romance for college students could be "romantically frustrating." When one author was doing his master's in Beijing, his girlfriend was in a city a thousand miles away. Although lack of access to ICT (including the telephone) helped them to practice the art of calligraphy, the author and his girlfriend found it vexing that they had to spend dozens of dollars on a commercial phone just to be able to hear each other's voice. It was also frustrating to find that all news reported in their correspondence, when received, was at least several weeks old.

However, the contrast between the authors' current condition and that in their recent past was not achieved easily. It entailed an academic progress into the doctorate and a physical migration from one side of the Pacific to the other side, all of which, unfortunately, is still not within easy reach for so many in this world. 
Second, a digital divide is also immediately dividing the authors from their respective loved ones and close friends. None of the authors' parents has access to a computer, let alone access to the Internet. One author's parents had their first phone in their whole lives just several months ago. Before that, the author and his parents had to depend on the snail mail for communication, in which case every piece of news, when received, is at least three weeks old. Response to that news when received can be two months outdated. This is clearly incompatible with any conception of the "modern information age." None of one author's sisters and their families has either a phone, computer, or Internet connection. One author's parents-in-law do not know how to use the computer and lack access to the Internet despite the fact they do have a computer as a gift from the author. In this sense, the digital divide is created by more than just the non-possession of the physical ICT devices. It also involves, for instance, education, knowledge, and practice.

Information in this paragraph about the general use of the Internet in China comes from one author's friend who currently studies at a University in Nanjing, China. Although top universities in China may have broadband Internet connection in students' dorms, the majority of Chinese universities still lack this facility. Even the use of dial up connection is sparse. Classrooms generally do not have access to the Internet. The majority of academic departments do not have computer labs except for departments of science and technology. Though the situation in large cities such as Beijing and Shanghai may be different, general households in medium-sized and small cities do not have Internet access.

According to China Internet Network Information Center (2003), the current total number of computers with Internet connection is 20.83 million, among which 4.03 million have broadband connection, 14.80 million have dial-up connection, and 2 million have other connections. Since China has a population of 1.3 billion, therefore, only $1.6 \%$ of the population has computers with Internet access. With further consideration of the fact that some Internet users may have more than one Internet-connected computers (e.g., at home and in office), the percentage of people with Internet-connected computers may even be less than $1.6 \%$. With the digital divide widening, the destiny (as impacted by ICT) of the more than $90 \%$ of Chinese population becomes an issue of great gravity.

Finally, what makes matters worse, the digital divide that handicaps China does not stop at the mere lack of physical devices of ICT. By electronically blocking information from its citizens, the Chinese go vernment is artificially creating a "virtual digital divide" that may divide the bulk of Chinese population from the "informed parts" of the globe. For the purpose of censorship over information, the Chinese government uses both legislative and technological means.

Legislatively, numerous regulations have been instituted to regulate the electronic transmission of information. Most recently, the State Council issued in September 2000 The Telecommunications Regulations of People's Republic of China and The Regulation on Internet Information Service. These regulations proscribe internet service providers (ISP) from production, dissemination, and publication of any content that is against the basic principles of China's constitution, derogates the state religious policies, or advocates illegal religions and cults. ISPs are further required to keep detailed logging of their subscribers' Internet activities so as to purge undesirable information promptly.

Technologically, governmental censorship over information is implemented both on a macro- and micro-level. On the macro-level, the government exerts control over electronic information through a fourtiered pyramidal struc ture. In the top tier, all connections to overseas networks must go through the central gateway operated by the Ministry of Information Industry. In the second tier, only ChinaNet, China GBNet, UniNet, and CNCNET are endorsed by the state to provide commercial services to the public. Other ISPs, which constitute the third tier, must subscribe to the state-endorsed service providers. The bottom tier, of course, consists of individual users of the Internet and the information they can access has undergone a filtering through all the previous tiers (Wang, 2001). On the micro-level, software such as "Filter King" are used to monitor, filter, and discourage "domestic access to various foreign news, 
human rights and adult sites deemed inappropriate or destructive to socialist principles” (Palser, 2001). Software that facilitates monitoring and filtering of email messages are also employed.

Personal experience from one author's friend corroborates the above claims. Ms. Li, who studies at a University in Nanjing, China, testifies that the sites of some American universities are completely blocked when she was applying to these universities. Other sites, as she experiences, were blocked periodically. When one of the authors was back in China in 2000, he could not access many sites acquired via search engines that contain "sensitive" information (e.g., pornographic or political).

\section{Conclusion}

Countless parts of this world are being impacted by rapid technological change with unprecedented magnitude. Yet the patterns of diffusion of ICT are drastically uneven. There is a valid concern about whether the rapid and uneven spread of ICT will further widen the "digital divide" that has already emerged among different groups and different locations. If ICT use proves to be associated with economic gains, the widening digital divide can only reinforce and deepen the existing socio-economic divide in the world and further marginalize the underprivileged. In this sense, technology is not equalizing but polarizing this world. By personally authentically the digital divide, the authors have illustrated that the digital divide is not distant and impersonal, a concern of someone else, but close, real, and very personal. The digital divide not only divides the industrialized and the privileged from the unindustrialized and the unprivileged, but can also divide the privileged from their loved ones and close friends. The digital divide is an issue of great personal pungency that merits our earnest attention.

\section{Note of thanks:}

The authors wish to thank Juan Li from Nanjing University of Science and Technology (China) who shared her knowledge and experience on the use of the Internet within China.

\section{References}

Attewell, P. (2001). The first and second digital divides. Sociology of Education, 74, 252-259.

Benedetto, R. (2000, April 19). Clinton enlists Net in battle against poverty. USA Today, p. $13 \mathrm{~A}$.

Bresnahan, T., Brynjolfsson, E. \& Hitt, L. M. (1999). Information technology, workplace organization, and the demand for skilled labor: Firm-level evidence. Working Paper No. 7136. Cambridge, MA, National Bureau of Economic Research.

Campbell, D. (2001). Can the digital divide be contained? International Labour Review, 140 (2), 119-141.

China Internet Network Information Center. (2003, January). Report on the state of Internet network development in China [in Chinese]. [On-line]. Available: http://www.cnnic.net.cn/develst/2003-1/ [2003, March 11].

Crews, C. (2000, February 28). Technology program works to close "digital divide." Philadelphia Tribune, p. 6G.

The digital divide: Black-white or rich-poor. (2001). Campus-Wide Information Systems, 18(2), p. 56.

Digital divide goes beyond Internet access. (1999, August 29). Jacksonville Free Press, p. 2.

Gates, H. L. (2000, January 12). Black to the future. Education Week, p. 72.

Goslee, S. (1998). Losing ground bit by bit: Low-income communities in the information age. Washington, DC: Benton Foundation.

Henderson, G. (2000, January 31). The digital divide. Emerge, p. 60.

Howland, J. S. (1998, October). The 'digital divide': Are we becoming a world of technological 'haves' and 'have-nots?' The Electronic Library, 16 (5), Oxford, 287-289.

Krueger, A. (2000, July 24). Net job searches change the market and the economy. International Herald Tribune, p. 8.

Lacey, M. (2000b, February 3). Clinton enlists top-grade help for plan to increase computer use. New York Times, p. A25.

Light, J. S. (2001). Rethinking the digital divide. Harvard Educational Review, 71. 709-733. 
Lu, M. T. (2001). Digital divide in developing countries. Journal of Global Information Technology Management, 4 (3), 1-4.

McKee, P. (1999, August 22). Navigating the digital divide. Washington Informer, p. 10.

Menou, M. J. (2001, April). The global digital divide; beyond hiCTeria. Aslib Proceedings, 53 (4), 112-115.

National Telecommunications and Information Administration. (1998, July 28). Falling through the Net II: New data on the digital divide. Washington, DC: U.S. Depart ment of Commerce. [On-line]. Available: http://www.ntia.doc.gov/ntiahome/net2/falling.html [2003, March 10].

National Telecommunications and Information Administration. (1999, July 8). Falling through the Net: Defining the digital divide. Washington, DC: U.S. Department of Commerce, National Telecommunications and Information Administration. [On-line]. Available: http://www.ntia.doc.gov/ntiahome/dn/index.html [2003, March 10].

National Telecommunications and Information Administration. (2000). Falling through the Net: Toward digital inclusion. Washington, DC: U.S. Department of Commerce, National Telecommunications and Information Admin istration. [Online]. Available: http://www.ntia.doc.gov/ntiahome/dn/index.html. [2003, March 10].

Office of the Press Secretary (1999, December 9). The Clinton-Gore Administration: Working to Bridge the Digital Divide, The White House.

Palser, B. (2001). The great online wall. American Journalism Review. November 2001.

Poole, G. (1996, January 29). A new gulf in American education, the digital divide. New York Times, p. D3.

Robison, K., \& Crenshaw, E. (2000). Cyberspace and post-industrial transformations: A cross-national analysis of Internet development. Paper presented at the annual meeting of the American Sociological Association, Aug. 2000, Washington, DC.

Sachs, J. (2000, July 26). Today's world is divided not by ideology but by technology. The Economist (London), p. 99.

Smith, M. D., Bailey, J., \& Brynjolfsson, E. (2000). Understanding digital markets: Review and assessment. In E. Brynjolfsson \& Kahin (2000). Human Development Report 2000. New York: Oxford University Press.

State Council. (2000). Regulation on Internet Information Service. [Online]. Available: http://www.cnnic.net.cn/policy/18.shtml [in Chinese]. [2003, March 11].

State Council. (2000). The Telecommunications Regulations of People's Republic of China [in Ch inese]. [Online]. Available: http://www.cnnic.net.cn/policy/19.shtml [2003, March 11].

U.S. Department of Commerce. (2000). Falling Through the Net: Toward Digital Inclusion. Washington, DC.

Wang, J. (2001). The Internet and e-commerce in China: Regulation, judicial views, and government policies. Computer and Internet Lawyer, January 2001, 12-30.

World Bank (2000, June). The networking revolution: Opportunities and challenges for developing countries. InfoDev Working Paper. World Bank Group, Global Information and Communication Technologies Department. Washington, DC.

\section{Biographies}

Xin-An (Lucian) Lu holds a Ph.D. in Organizational Communication and Leadership from Southern Illinois University-Carbondale. He is currently an Assistant Professor in Speech and Theatre Arts Department, Shippensburg University of Pennsylvania. Besides being a published poet, he has published articles on management, information technology, visual rhetoric, and oppression against women. His research interests encompass organizational studies, leadership, visual rhetoric, communication technology, and the "un-economics" of various aspects in modern life.

Dr. Hong Wang is an Assistant Professor in the Speech and Theatre Arts Department, Shippensburg University of Pennsylvania. She has much overseas teaching experience, and published in Chinese as well as in English. Her research interests inc lude communication technology, cultural semiotics, and intercultural communication. 